\title{
THE INTELLIGENCE OF THE JEWISH NATION
}

\author{
Lydia Megawati \\ State Islamic University (UIN) Alauddin Makassar \\ Email: lydia.megawati@uin-alauddin.ac.id
}

\begin{abstract}
Understanding Judaism must be able to distinguish between two things, namely Judaism as a nation and Judaism as a religion. Jews as a nation known as a nation that is superior or superior to race or nation the other. This is not without reason and cause, the long journey of the Jews and the forgings of life that make them strong. The expulsion that occurs constantly being made the nation's Jews be spread in the whole world, the road to be able to still survive life is to have the skill and certainly intelligence to think. Intelligence that they have formed from the intake of food that has been observed since the age of the womb. The food that is consumed is always observed in many cases.
\end{abstract}

Keywords: Jewish, smart, kosher, big day

\section{INTRODUCTION}

Basically, part of the religion is having a village courtyard, the groundwater. In the Testament, the New Christian religion is not mentioned that Rome or the Vatican is a land sacred to the people of the Nazarenes. In the Koran, it is not mentioned that Saudi Arabia or Iraq are holy lands for Muslims. However, there are 750 references concerning Jerusalem in the Bible and more than 2000 references regarding Jerusalem in the book of sacred Jewish. Thus, the 
groundwater has a hierarchy that is large in the Jewish than in other religions. Christianity is not about groundwater and Islam is also not about the groundwater, but for Judaism groundwater is holy is everything.

The Wall that surrounds the temple of the Holy became a symbol of salvation at once conflict. Pray at the Wall West has become a dream for many generations of Jews, touching on Rock stone that has been changed because of the weather is a thing that is liberating. For many generations, the Wall is also a symbol of redemption, a symbol of the embodiment of the Torah in the world. If the Way of the Lord is the fertility and solely only aisle peace were created, why wall it becomes a conflict and discord?. By the government of Israel, the hills Kenizah has been submitted to the authority of religion Islam to be regulated as a place that is important for the worship community of Islam. The people of the Jews had been waiting from generation to the generation next to come back to Israel, even require a long time to them back to where all the prayers performed for 3 times in a day ${ }^{1}$.

Of the various sources of literature were written, the Jews are a nation that has advantages, as well as genetics, are known as intelligent. Ignorance is a sin that was unforgivable for the Jews, according to Friedrich Gentz . The Jew is seen as a nation that is intelligent and they hated and feared as a

1 Rabbi Dov Berkovits dan Kelly James Clark, Anak-anak Abraham: Kebebasan dan Toleransi di Abad Konflik Agama (Cet. V: KANISIUS: Yogyakarta, 2018), p. 65. 
result of things that. Hitler wrote in his book Mein Kampf, the ability of intellectual Jews forged thousands of years and the Jews are seen having intelligence that beyond the ordinary because for centuries they live oppressed and always driven and does not have a civilization. So that of all the events that happened they take and pluck a lesson to come out of the difficulties of life. Intellectual Jews not ever be constructive but always destructive ${ }^{2}$.

Experience live the bitter as well as its ability to face the challenges as part of the selection of nature that has brought on the hypothesis that the Jews have intelligence because of the attitude of optimism in the face of suffering to endure life. Pressures of life, bitterness, and the danger that threatens her as the minority deliver them able to anticipate any crisis that it faces. Struggle, pain, and efforts to fight the enemy forming genetics in themselves they are. Genetics those Jews who came from Europe North (Jewish Ashkenazi ) have differences, due to their ability to overcome the crisis which then increases the intelligence and ability they anticipate their environment and unique ${ }^{3}$.

People Jewish judge themselves as a nation that is superior and racial superiority, to maintain the advantage that they are very bigoted towards marriage, to not do the wedding

${ }^{2}$ Georges Van Vrekhem, Rabbi Dov Berkovits dan Kelly James Clark, Anak-anak. Abraham: Kebebasan dan Toleransi di Abad Konflik. Agama (Cet. V: KANISIUS: Yogyakarta, 2018), p. 288

${ }^{3}$ Toto Tasmara , Yahudi, Mengapa Mereka Berprestasi (Cet. I: Jakarta: Sinergi, 2010), p. 87. 
along with the person who is not Jewish. This was done, to avoid mixing their Jewish order as the chosen people.

Judaism as religion refers to people who are Jewish. The Jewish Agana Law (Halakba) describes who has the right to be called a Jew:

1. Tribe nation Jewish

a. A child who is born of a father and mother who have the blood of Jews is called the Jewish original.

b. A child who is born of a father Jew and mother of the nation the other entered in the category of Jewish class II.

2. Jews who embraced the religion of the Jews according to the laws of the Jews.

\section{RESULTS AND DISCUSSION}

The level of Jewish intelligence is closely related to genetics and not just the influence of the environment so that it is substantially influenced by heredity. In the century midRabbis Jews were known as person intelligent, pious, and have high status. Rabbi regarded as a human being virtuous whose life is spent with reading books, memorize and hum a book

${ }^{4}$ https://id.wikipedia.org/wiki/Yahudi 
of scriptures, as well as guiding the people in the Synagogue ${ }^{5}$ or Yeshiva (similar to a pesantren or religious school).

Of the whole thing at the top, which is not to be missed is the halal food. Some laws regulate every aspect of the lives of the Jews and are concerned also about the food, the law is known as kashrut. Law is to give guidance on food that can be eaten and how the food was prepared. The word kosher has meaning: inappropriate or good, used to describe food that is allowed by the laws of this. There are many laws regarding food mentioned in the Torah and some of them come from the interpretations of the Rabbis. Not only because of the order books of the sacred course, but the law of food also provides the function of health and form the basis of immunity strong. The level of observance among the Jews is very varied, some groups of the Jews run the entire law, most others just follow the rules specified course. The things that need to be considered according to the laws and regulations of the Jews are:

${ }^{5}$ The synagogue is a place important to worship and become the center of the lives of the Jews. Derived from a Greek word meaning " a gathering place ", synagogues were important to the survival of Judaism. When the Temple both were destroyed in the year $70 \mathrm{AD}$, the Rabbi developed the idea of the house of worship to maintain that religion and those who are in the diaspora still alive. The important war of the Temple was never forgotten. In the present, when the synagogue was built, most of the walls are left not plastered intended to commemorate the destruction of the Temple. See Philip Wilkinson and Douglas Charing, Encyclopedia of Religion (Cet. III: Kanisius : DI Yogyakarta, 2018), p. 152. 
1. Halal shop, kashrut law or Kosher is very complex. With the store kosher it easier and safer for the Jews to buy food. The majority of the foods that form of packaging has the kosher label to indicate that a rabbi had visited the factory and ensure that food that has been processed with a good and true.

2. Food small, the food that is not meat and butter called Parve $^{7}$, the food includes fruits, vegetables, rice, eggs, and lentils (grains). Fruits and vegetables should be checked as a whole before it is eaten, to avoid the insects because the law judge all insects are not kosher.

3. Meat and butter. Animals that hoof split and chew the cud, such as sheep are considered kosher, while pigs unclean. Animals must be slaughtered by people who are trained to minimize the sense of pain when the animals are slaughtered. Blood must be separated from the meat of animals because the blood lacks the life of the animal. Meat and products of milk are not

${ }^{6}$ Kashrus, is a term in the law on food Jew, in accordance with halakha (law of the Jews). Kashrut or kosher has the meaning of worthy (fit for consumption by Jews). Food that is not following the laws of Jewish termed by treifah, referring to the animal that is slaughtered by way injured or die as a result of wild animal capture so it is not feasible to eat. https://id.wikipedia.org/wiki/Kosher, (Accessed April 1320 21).

${ }^{7}$ Pronounced Pah-riv or pahr-veh, is a Yiddish term for something that is neither meat nor dairy. Legal Jews do not allow someone to cook or consume meat bersaam with products of milk. https://jewishcentersurabaya.wordpress.com/blog/apa-itu-parve/ , (Accessed April 13, 2019). 
allowed to eat simultaneously and home stairs kosher must have two sets of furniture to keep that product meat and butter remain separate.

4. Food sea. Only fish with fins and scales such as salmon, freshwater fish, and fish oil pills are considered halal. All kinds of shellfish and other seafood are not allowed ${ }^{8}$.

5. Easter. On the day of Easter, there is the food of certain were not allowed to be consumed. To identify the thing is, some packaged food gives labeled "kosher for Passover ".

6. Gardens Wine and its production. Treatments are serious must be executed when managing the gardens wines are kosher. Torah gives instructions that the grapes from the garden that is still just not able to be directly used by the fourth and every seven years the garden of wine must be emptied. In the past the Jews were forbidden to drink wine because drinking wine was part of pagan worship, so they decided to produce their wine. Later, strict regulations were applied for the production of halal wine. For example, only those Jews who obey are allowed to oversee the process of production. The winery has a Rabbi who helps

${ }^{8}$ Philip Wilkinson and Douglas Charing, Encyclopedia of Religion, p.162. 
oversee all the requirements before the issuance of the halal label.

7. The laws of Kashrut are applied to ritual objects including the Shofar ${ }^{9}$ those made from the horns of halal animals contained in the Torah and Meruzah must come from halal animals ${ }^{10}$

For the nation Jewish, education is not the only key to success but as part of the piety social and fulfillment of the command of God. The attention of the parents is not only limited to the education general course, but the education of religion also performed with intensive. Since the period of childhood, they are required to study the Torah and Talmud (Mishnah and Gemara). The Talmud is a collection of commentary or opinion of the Rabbi of the verses of the Torah and Mishnah is a book that contains the codification of the law of worship and guidance of mind and character.

Nation Jews and their descendants believe that they have the intelligence that high, regard this that gave a boost to themselves to build and refine potential in themselves they are with full consciousness. Starting from a system of education that is regulated by either based on three principal, namely:

${ }^{9}$ Shofar or spelled shofar, is a tool of music inflatable which is made from the horn of an animal that is kosher and used for ritual religious Jews. Closely related to two important Jewish days, namely Rosh Hashanah and Yom Kippur. https://id.wikipedia.org/wiki/Shofar , (Accessed on April 13, 20 21).

10 Philip Wilkinson and Douglas Charing, Encyclopedia of Religion, p. 163. 
1. Sticking firmly to the concept of monotheism, believing the one God as the foundation of life is the main.

2. Sticking firmly to the ethics that refers to the Ten Commandments of God that is received by the nation's Jews at Mount Sinai.

3. Hold fast to the Torah ${ }^{11}$.

The concept of Jewish education is a synergy between religious and general knowledge. The synergism between the two gives the right of authority to each parent in the family and the religious leader (Rabbi) in the Synagogue. The system of education Jews inherited is hereditary and is taught at home by a father who has the role of large as well as education in a house of worship (synagogue) by the Rabbi.

In raising their children, the parents must have the view that life is a journey toward the triumph of Judaism (Jews Journey) a journey that does not know the word is completed. As facer street, they are responsible for making their sons and daughters as a next-generation successor to the more robust with still holds the traditions, values, rituals, and culturally Jewish. It is important to educate the children they are, known for the term dogma (language Hebrew that has meaning: the example, the behavior, role model). Parents are examples and

${ }^{11}$ John Sehandi, Pendidikan Cerdas Orang Yabudi, http://yohanessehandi.blogspot.com/2016/06/pendidikan-cerdasorang-yahudi.html, (Accessed on 25 April 2021). 
role models for their children, but not all of their ideal behavior is an example for their children. The moral values taught are basic education teaching for children, including the following:

1. Kavod: respect or respect others

2. Tredekah box: Child- Jews, in general, have a box of savings, and time has been filled they will deposit into a bank or bring money are to be donated in the activities of the charity.

3. Gemilut Hasadim: loving others. Give clothes to people not capable, active in the activities of social, visit the sick and grief (of course, preferably scope Jewish)

A principal tradition that is taught to be a tradition in the life of the national Jewish, namely:

1. Likes to read, Jewish parents are very consistent in dictating the importance of reading books. People Jews are people who have an interest in reading the highest. The habit of reading is only to be defeated by the people of Japan who have a habit similar. It is estimated that the Japanese spend 12 books read per year. Universal law applies to anyone who likes to read books, get information. Anyone who obtains information gets knowledge. Anyone who mastered the knowledge, master the technology. Anyone who 
mastered the information, knowledge, and technology then prepared into King of the World ${ }^{12}$.

2. The role of the mother, the pattern of parenting, and child education at home, the position of a mother has an important role in shaping the character of her children. Teachings are inherent in establishing trust themselves in verbal is one of the foundations are strong so that children of Jewish able to explore the natural surroundings. The pattern of education at home as well as historical and challenges that faced the Jews growing need for achievement which is quite high $^{13}$.

3. Directing children, the age when the child first-time entry to school is a period of very happy and celebrated full of joy (the people of Europe East), complements the sweetness given to children as a form of encouragement and happiness. In a Jewish family environment, children are directed to have dreams and strive to achieve and realize those dreams ${ }^{14}$.

4. Solidarity and Generosity, children have been introduced to tredekah even children are required to have their tredekah box.

\footnotetext{
12Toto Tasmara, Yabudi, Mengapa Mereka Berprestasi, p. 120.

13 Toto Tasmara, Yabudi, Mengapa Mereka Berprestasi, p. 128.

14 Toto Tasmara, Yahudi, Mengapa Mereka Berprestasi, p. 131.
} 
5. The peak of the Feast, forgiveness, and repentance is reflected in some of the important holidays in Judaism. The highlight of the feast is celebrated in the month of September and October, dependent on the calendar Jewish. Here is the highlight of Hari Raya:

a. Rosh Hasanah (Year New Jewish), the feast has marked the creation of the world and the court when God gives the reward for deeds good and the bad as well as the determination of the provision them in the years to come. During the ten days following, known as Day- the day Solemn, people are given a chance to repent, because the court last Allah on the day of Yom Kippur. When the implementation of Rosh Hasanah, worship at the Synagogue is a long, solemn, and filled confession of sins and prayers of repentance. Then the ritual is important more is sounding the shofar which is made from animal kosher as means call consciousness, giving inspiration to all people to reflect on the year that will end up and decided to live a life that is better than the year that will come.

Celebrated on the date of the 1 st and 2 nd month of Tishrei, the month 7 th in Calendar Jewish, in the calendar $\mathrm{AD}$ in the month of 
September- October ${ }^{15}$. Calendar Jewish or Calendar Hebrew is the calendar Lunisolar that is used by the nation's Jews. Having 12 months and had a day as many as 29 or 30 and the number of days per year is $354^{16}$.

b. Yom Kippur, the most sacred in the calendar Jews is Yom Kippur which commemorated 1 Tishrei in Calendar Jewish ${ }^{17}$. In addition to those who were sick or were in treatment, every person who lived in the above Bar or Bat Mitzvah undergoes fasting for 25 hours and most big people spend the whole day was to pray at the synagogue to pay compensatory damages to the creators. Worship Yom Kippur ends with the blowing of the shofar, and each man returned to the house with a feeling clean and with the purpose of life that is new. At the evening celebration, things that become a tradition of the Jews is eating an apple are dipped into honey, with the hope that the new it would be sweet. They also eat fruits that are exotic that rarely they eat when days are usually as well as wearing clothes new.

15 https://id.wikipedia.org/wiki/Rosh_Hashanah (Accessed on 5 April 20 21)

16 https://id.wikipedia.org/wiki/Kalender_Yahudi (Accessed on April 5, 2021) April 2021)

17 https://id.wikipedia.org/wiki/Yom_Kippur (Accessed on 5 
6. The celebration of the feast of the Jews

a. Easter, Pesach (Passover) warning that is associated with the exodus of the nation's Jews from Egypt. In celebration of this, every family who celebrates will be reminded of the pain that is covered during becoming slaves king Pharaoh and saved by God through the guidance and leadership of the Prophet Musa. as that when it was given a miracle capable of splitting the Sea Red to the land that was promised.

b. Shavuot, the celebration as a commemoration down of the Torah at Sinai, on the day it was read back Ten orders God (The Ten Commandments).

c. Sukkot or hut, which lasted a week is celebrated five days after the Peak Day feast of the Solemn. Sukkot commemorates when the people of Israel live in a place to stay temporarily during the period of the Exodus from Egypt and celebrate the collection

d. Hanukkah, is celebrated to commemorate an important historical event. People Jews in Israel ancient not allowed to run their religion. Battles are led by Judas Maccabee were won by them and managed to open the Temple that had been used by the pagans. Lights perennial lit even though they only have a little oil that is taken into account 
only able to survive for one day will be but able to survive for eight days.

e. Purim, celebrated with a festive -month in March. The ceremony principle that related to Purim is, reading the Megillah (Book of Esther). This book contains the history of a Jewish woman named Esther and her cousin Mordecai who lived in Persia in the 5 th century BC. They made a plan to stop the killings of the people of Jewish Persians by officials of the kingdom that is cruel named Haman. The Megillah is read on the night of Purim and the day of its feast, the Jews gather in the synagogue to read it. The book of Esther has not contained the name of God as our books we Jews more and the people of the Jews believe that the case is demonstrated God always works even in ways that are not visible. Besides listening to the reading of Megillah, the Jews also eat a variety of foods feast, mutually exchanging gifts of food, and give charity love. Some Jewish communities organize parties and processions, both adults and children wearing colorful clothes provide a lively atmosphere of celebration.

f. Tu Bishvat, is known as the New Year for plants. According to the story of history, $10 \%$ of the results of production agriculture must be presented to the priests and the poor in 
celebration of this. In Israel today, Tu Bushvat is seen as a time to plant trees new and when to eat the fruits of the land are planted. The celebration is held in the month of January when the season of spring.

g. Shabbat, the Jewish day of rest. Starting every day Friday at the time the sun was setting circuitry lit candles Shabbat and ends on Saturday evening next. " Remember going to the seventh, let you do not work ", any one of the Ten Commandments of God. As God rested on the seventh after creating the world, the Jews who obey do not perform activities or activities to work on the day of Shabbat. According to tradition, the Sabbath is considered a time for worship, rest, and gathering with the community. Before you start the day Shabbat, most of the Jews wash their hands as many as three times by using a cup, particularly that there are two grips. Then the Jews providing bread challah as much as two pieces remind them at the time of doing wanderings in the desert wilderness. God gives them manna as food daily, but on Friday they receive 2 times as much in number. This is contained in the QS al- A'Raf /7: 160: 


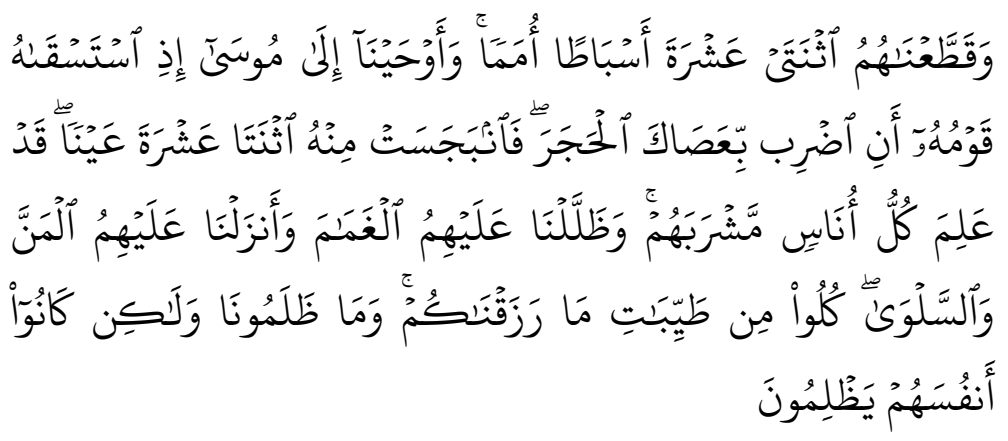

Translation:

and they Us to be two twelve tribes which each amounted great and We revealed to Musa when his people asked for water to him: " Strike the rock it with thy rod !". Then there were flashes of her two dozen eyes water. Verily, each tribe knows its drinking place. and We naungkan cloud on top of them, and We sent down to them manna and salwa. (We said ): "Eat the good of anything that has We give it to you ". they do not Persecute Us, but they were always Persecuting her own.

One of the favors of God to them is : they are always shaded by clouds at the time they walk in the hot scorching desert sands. manna Ilah: food sweet as honey. Salwa is He: bird countrymen quail ${ }^{18}$.

The ceremony that marked the end of the day of Shabbat is called Havdalah, which means separation. The

\footnotetext{
${ }^{18}$ Kementrian Agama Republik Indonesia, Alquran dan Terjemahnya, p.171
} 
ceremony's highlight candle spiral (reminiscent of the light that is created by God when bringing the light of order to the world, there is the axis that many symbolizes the unity of the people Jewish), wine and spice scented fragrant. Havdalah emphasize the separation between the Shabbat holy and the other in a whole week.

Shari'a and rituals in the worship of God in the form of prayer are done three times in a day, ie on time in the morning, noon, and night day. The congregational prayer is a minimum of ten people. Before praying, they also oblige to purify themselves from habits by performing ablution. in prayer, they are also required to cover the head and genitalia same as in Islam. Furthermore, they also perform fasting which is included in the Jewish religious law. Fasting or fasting performed on days specified as the commemoration of Yom Kippur for 24 hours on the date of 10 Months of Tishri and every day Monday and Thursday ${ }^{19}$.

In Judaism, the events of life that are important is always marked with a ceremony special. Circumcision of children is a habit Jews were common and come since the days of the Book of Saints. Bar and Bat Mitrwah mark when a child has become a member of the adults in the community. Some communities of Jewish Reformer celebrate the coming of age of adulthood both men and women at the age of 15 and 16 years in a ceremony that is called confirmation. There

\footnotetext{
${ }^{19}$ Abd. Rahim Yunus, Ukhuwah Multikultural (Cet. I; Pustaka Almaida, Gowa), p. 105-106.
} 
is a habit of the Jews were specifically tagged marriage, death, and mourning. The whole cycle of life is celebrated in the open, which emphasizes the nature of the communal life of the Jews ${ }^{20}$.

In understanding the people of choice, most adherents of Jewish thought that religion and nation not be separated. They believe that God has chosen them as a nation or people of choice in the world. Proven with the agreement of the Lord and Abraham and the Torah that was given to Moses. The land of Canaan as the groundwater they were promised by God to the Israelites appropriate that contained in the Torah. In addressing the Wall of Lamentations of the adherents of Jewish thinking that the wall has a meaning and bonding inner when they pray they believe that God will grant all requests. As a community of faith, followers of the religion of Jewish different from Christianity and Islam. The difference is due to the concept of belief, behavior, and religious experience. The majority of the Jews rejected the existence of Jesus as Savior Congratulations, they assume that the Savior Congratulations are going to bring salvation, and do not require the arrival of a second. The adherents of religious Jews believe that the concept of the Trinity is a thing that is contrary to the oneness of God, especially the belief in Christianity that Jesus is the son of God. The attitude of the adherents of religious Jews do not recognize the teachings of

${ }^{20}$ Philip Wilkinson and Douglas Charing, Ensiklopedi Agama, p. 168. 
Islam because of the tradition at the time it was asserted that Muhammad was not by the expectations of those of someone who awaited ${ }^{21}$.

It was appropriate in the Koran that although the revelations were mentioned repeatedly by Muhammad to the people of Medina are similar to the revelation in the law will, but differ in details. People Jews doubted the authenticity of the Qur'an was revealed in the language of Arabic is not like the Torah was revealed in the language of the Hebrew and the context of the culture of the nation of Israel. Differences discourse This explains a lot of mismatches and irregularities were found in the Biblical Jews were found in the Testament New and interpretation of the Christians ${ }^{22}$.

In the travel history of the people of the human, not known to many shades of groups of religious who were born based on similarity of belief, whichever comes in the face of the earth. Religion is born and recognized by its followers based on the belief that its nature receives revelation, inspiration, or a mandate from outside itself. The basis of revelation or inspiration is composed of a ritual system of servitude to God. Religion can be an adhesive factor. The religions that exist in the world are very not possible to put together, such as the impossibility of uniting tribes, ethnicity,

${ }^{21} \mathrm{Ilim}$ Abdul Halim, Agama Yahudi Sebagai Fakta Sejarah dan Sosial Keagamaan, Religious: Jurnal Agama dan Lintas Budaya I, no 2 (2017): p. 144.

${ }^{22}$ Ilim Abdul Halim, Agama Yahudi Sebagai Fakta Sejarah dan Sosial Keagamaan, Religious: Jurnal Agama dan Lintas Budaya I, p. 145. 
and nation. In the Qur'an, it is understood that humans have the instinct of diversity. In the human mind is embedded a sense of wanting to return to its origin, namely Baitullab ( House of Allah). In philosophy and science knowledge and understanding of religion-state, that man is not composed of elements of matter alone, but material and non-material. As with all religions, including religious Jews emphasize the importance of brotherhood, harmony relationship with the Creator, God and relationship harmony with fellow beings. Relationship with God ( aqidah monotheism ) to perform worship to bring ourselves to God is a part of important teachings of the Jews ${ }^{23}$.

The essence of the teachings of Jewish lies at Ten Word of God ( The Ten Commandments) which contains :

1. I am the Lord, the Lord who issued you from the Earth of Egypt, out of the nest servitude, not aka $n$ no longer God for you in front of me. Do you make a sculpture that was carved as well as images of any of that is in the heavens and what that exist on earth, and not also in the water, do not worship and bow to him, because I'm here Lord, Lord You, Lord are jealous?

2. I will check out the sins grandmother your fathers on children and grandchildren, to the generations of the third or fourth of the haters- and I make kindness to

${ }^{23}$ Abd Rahim Yunus, Damai Dalam Islam: Perspektif Cita dan Fakta (Cet. I: Alauddin University Press: Makassar, 2012), p. 24. 
thousands of lovers and the custodian of the will-my will.

3. Do not call by the name of God, your God is wrong because God will not forgive anyone who says his name wrong.

4. Remember the Saturday due to his holiness, six days you work and make matters you. The day of the seventh, then her Saturday from God. Do not make the job any kind, you and the daughters of you, a servant of you, men and women, animals you and the people who live alongside you who enter the doors you, because on the sixth day before the Lord has member at sky-earth and sea along with all that there is in it, then God rested on the seventh, and because the Lord gave catty and purify the day Saturday.

5. Honor your father and your mother so that your days ( age ) on top of the earth becomes long which has been awarded the Lord unto you.

6. Don't kill

7. Don't commit adultery

8. Don't steal

9. Don't testify falsely / lie 
10. Do not be greedy to house relatives, do not want wife's relatives, do not be slave or jariyahnya, his ox or donkey and what course are owned by relatives ${ }^{24}$.

\section{CONCLUSION}

As a religion that upholds high ethics, religious Jews looked at religion and morals as sanctity. Holy in the sense of leaving all forms of idolatry and hold unwavering belief and worship that has revealed God to man. Sanctity is also an attitude opposed to prioritizing the interests of themselves alone at the expense of others

Intelligence is also not just about the success of the real visible in front of eyes moved at several achievements height are exalted. Not just about the numbers and values are high. Intelligence can also be defined as the ability of a person to be able to adapt to the surrounding environment and be able to blend in without feeling uncomfortable, even criticizing the surrounding environment. Intelligent in bringing self- fused premises environment bai Kalam as well as groups and individuals. Communications were established with well, secret personal and interpersonal which in Islam is known brotherhood.

Build ukhuwah advance of human and among fellow creatures of God more is part of an important teaching of

${ }^{24}$ Ahmad Syalaby, Perbandingan Agama: Agama Yabudi, p. 309-310. 
religion Jewish. Pengimplemntasinnya is the way humans were always keeping the safety of the plants as well as plants. This is also stated in the Torah. Against fellow human beings, Jews taught the importance of working together in favor and please help, terms this is expressed in the Book of Old Testament ${ }^{25}$.

\section{REFERENCES}

Abdul Halim, Ilim. Agama Yabudi Sebagai Fakta Sejarah dan Sosial Keagamaan, Religious: Jurnal Agama dan Lintas Budaya I, no 2 (2017).

Berkovits, Rabbi Dov dan Kelly James Clark. Anak-anak Abraham: Kebebasan dan Toleransi di Abad Konflik Agama. Cet. V: KANISIUS: Yogyakarta, 2018.

Kementrian Agama Republik Indonesia, Alquran dan Terjemahnya.

Tasmara, Toto Yahudi. Mengapa Mereka Berprestasi. Cet. I: Jakarta: Sinergi, 2010.

Vrekhem, Georges Van. Hitler \& His God terj. Noor Cholis dan Irwan Rouf, Tuban Hitler. Cet. I: Jakarta: Mediakita, 2011.

25 Old Testament, the Book of Leviticus: People Levites: 25; 3536. 
Wilkinson, Philip dan Douglas Charing. Ensiklopedi Agama. Cet. III: Kanisius: D.I. Yogyakarta, 2

Yunus, Abd Rahim. Damai Dalam Islam: Perspektif Cita dan Fakta. Cet. I: Alauddin University Press: Makassar, 2012

https://id.wikipedia.org/wiki/Kosher, (Accessed April 13 2021).

https://jewishcentersurabaya.wordpress.com/blog/apa-ituparve/, (Accessed April 13, 2019).

https://id.wikipedia.org/wiki/Shofar, (Accessed on April 13, 2021).

http://yohanesehandi.blogspot.com/2016/06/ Pendidikancerdas-orang-yahudi.html, (Accessed 25 April 2021).

https://id.wikipedia.org/wiki/Rosh_Hashanah (Accessed on 5 April 2021)

https://id.wikipedia.org/wiki/Kalender_Yahudi (Accessed on April 5, 2021)

https://id.wikipedia.org/wiki/Yom_Kippur (Accessed on 5 April 2021) 